\title{
ANALISA PENYEBAB TERJADINYA KONFLIK HORIZONTAL DI KALIMANTAN BARAT
}

\author{
Alwan Hadiyanto \\ Dosen Tetap Program Studi Ilmu Hukum UNRIKA
}

Sesuai dengan Undang-undang Dasar 1945, tujuan bangsa Indonesia adalah menciptakan masyarakat yang adil, makmur dan sejahtera dalam negara kesatuan Republik Indonesia. Dengan demikian merupakan tanggung jawab dan kewajiban setiap warga negaranya untuk turut serta dalam mewujudkan keamanan dan kesejahteraan di seluruh wilayah Indonesia dan berhak untuk hidup dengan bebas dan merdeka di setiap wilayah negara kesatuan Indonesia.

Hak hidup ini telah dijamin dalam Undang-undang No. 39/1999 tentang hak asasi manusia. Dengan demikian setiap suku bangsa di Indonesia mempunyai hak untuk hidup merdeka di setiap wilayah tempat tinggalnya. Untuk itu diperlukan suatu kesadaran dari tiap suku bangsa untuk menjunjung tinggi supremasi hukum dan pemahaman terhadap norma yang ada pada masyarakat setempat.

Mengingat begitu beragamnya latar belakang dan tingkat sosial masyarakat, maka persoalan hak dan kewajiban senantiasa muncul menjadi konflik sosial yang berkepanjangan dan terjadi di berbagai daerah. Konflik yang menggunakan simbol etnis, agama dan ras muncul yang mengakibatkan jatuhnya korban jiwa dan harta bagi pihak yang bertikai. Dengan demikian juga terjadi pelanggaran hak hidup damai dan sejahtera dalam bermasyarakat.

Keragaman suku bangsa merupakan kekuatan bangsa Indonesia. Kemampuan untuk mengelola keragaman suku bangsa yang besar diperlukan untuk mencegah terjadinya perpecahan yang akhirnya akan mengganggu kesatuan bangsa.

Kerusuhan dan pertikaian yang terjadi di berbagai daerah di Indonesia menunjukkan antara lain kurangnya kemampuan pemerintah dalam mengatasi penyebab terjadinya konflik sosial antar masyarakat. Konflik muncul dengan menggunakan simbol-simbol etnis, agama, dan ras. Hal ini kemungkinan terjadi akibat adanya akumulasi "tekanan" secara mental, spiritual, politik sosial, budaya dan ekonomi yang dirasakan oleh sebagian masyarakat.

Seperti halnya konflik antar etnis yang terjadi di Kalimantan Barat, kesenjangan perlakuan aparat birokrasi dan aparat hukum terhadap Suku Asli Dayak dan Suku Madura menimbulkan kekecewaan yang mendalam yang meledak dalam bentuk konflik -konflik horizontal. Masyarakat Dayak yang termarjinalisasi semakin terpinggirkan oleh kebijakankebijakan yang diskriminatif yang mengeksploitasi kekayaan alam mereka. Sementara penegakan hukum terhadap salah satu kelompok tidak berjalan sebagaimana mestinya. Kasus yang terjadi ini menunjukkan sulitnya penegakan hukum dan hak asasi manusia di Indonesia. Adapun yang menjadi permasalahan dalam penelitian ini adalah penyebab terjadinya konflik 
horizontal di Kalimantan Barat serta penanganan yang dilakukan oleh pemerintah dan masyarakat setempat.

Pada negara yang memiliki keragaman suku bangsa masalah antar suku merupakan hal yang seringkali muncul. Demikian juga Indonesia, dalam hal ini yang dapat dijadikan suatu gambaran adalah konflik antar etnis di Kalimantan Barat. Konflik yang timbul antara Suku Dayak dan Madura.

Konflik adalah timbulnya suatu pemahaman yang tidak sejalan antara beberapa pihak. Selain itu dapat juga timbul sebagai pertentangan kepentingan dan tujuan antara individu atau kelompok. Hal ini terjadi jika dalam hubungan tersebut terjadinya suatu kesenjangan status sosial, kurang meratanya kemakmuran serta kekuasaan yang tidak seimbang ${ }^{1}$ Kepentingan dan keinginan-keinginan yang tidak lagi harmonis akan membawa masalah dalam hubungan antara individu atau kelompok yang satu dengan yang lainnya. Seperti hanya yang terjadi dalam hubungan kelompok etnis Suku Madura dan Suku Dayak.

Kehidupan bermasyarakat Suku Dayak dam Madura memang seringkali banyak mengalami pergesekan karena kurangnya pemahaman antar budaya dari kedua belah pihak.

Untuk penelitian kasus yang terjadi antara kedua suku ini akan digunakan terori konflik Simon Fisher dan Deka Ibrahim dkk(Th. 2002)

Teori Kebutuhan Manusia :

" berasumsi bahwa konflik yang berakar dalam disebabkan oleh kebutuhan dasar manusia-fisik , mental dan sosial yang tidak terpenuhi atau yang dihalangi.”

Teori Identitas :

berasumsi bahwa konflik disebabkan oleh karena identitas yang terancam yang sering berakar pada hilangnya sesuatu atau penderitaan dimasa lalu yang tidak terselesaikan.

\section{ANALISA PENYEBAB KONFLIK DAYAK DAN MADURA}

Penduduk asli Kalimantan Barat adalah Suku Dayak yang hidup sebagai petani dan nelayan Selain suku asli, suku lainnya yang juga telah masuk ke bumi Kalimantan adalah Melayu, Cina, Madura, Bugis, Minang dan Batak.

\footnotetext{
${ }^{1}$ Thomas Sunaryo."Manajemen Konflik dan Kekerasan. Makalah pada Sarasehan tentang Antisipasi Kerawanan Sosial di DKI. Diselenggarakan oleh Badan Kesatuan Bangsa Prop.DKI tgl. 15-17 September 2002, di Bogor.
} 
Dalam berkomunikasi penduduk yang heterogen ini menggunakan bahasa Indonesia atau Melayu sebagai bahasa sehari-hari. Tetapi karena tingkat pendidikan mereka rendah, kebanyakan mereka memakai bahasa daerahnya masing-masing. Dengan demikian seringkali ditemui kesalahpahaman di antara mereka. Terlebih jika umumnya orang Madura berbicara dengan orang Dayak, gaya komunikasi orang Madura yang keras ditangkap oleh Orang Dayak sebagai kesombongan dan kekasaran.

Kebudayaan yang berbeda seringkali dijadikan dasar penyebab timbulnya suatu konflik pada masyarakat yang berbeda sosial budaya. Demikian juga yang terjadi pada konflik Dayak dan Madura yang terjadi pada akhir tahun 1996 yaitu terjadinya kasus Sanggau Ledo, Kabupaten Bengkayang (sebelum pertengahan tahun 1999 termasuk Kabupaten Sambas), di Kalimantan Barat. Konflik sosial sepertinya agak sulit terpisahkan dari dinamika kehidupan masyarakat Kalimantan. Setelah itu, pertikaian antar-etnis terjadi lagi di Sambas, lalu disusul di Kota Pontianak, dan terakhir di Sampit serta menyebar ke semua wilayah di Kalimantan Tengah.

Orang Dayak yang ramah dan lembut merasa tidak nyaman dengan karakter orang Madura yang tidak menghormati atau menghargai orang Dayak sebagai penduduk lokal yang menghargai hukum adatnya. Hukum adat memegang peranan penting bagi orang Dayak. Tanah yang mereka miliki adalah warisan leluhur yang harus mereka pertahankan. Seringkali mereka terkena tipudaya masyarakat pendatang yang akhirnya berhasil menguasai atau bahkan menyerobot tanah mereka. Perilaku dan tindakan masyarakat pendatang khususnya orang Madura menimbulkan sentimen sendiri bagi orang Dayak yang menganggap mereka sebagai penjarah tanah mereka. Ditambah lagi dengan keberhasilan dan kerja keras orang Madura menelola tanah dan menjadikan mereka sukses dalam bisnis pertanian.

Kebutuhan dasar yang tidak terpenuhi merupakan dasar dari munculnya suatu konflik ${ }^{2}$. Masyarakat Dayak juga mempunyai suatu cirri yang dominan dalam mata pencarian yaitu kebanyakan bergantung pada kehidupan bertani atau berladang. Dengan masuknya perusahaan kayu besar yang menggunduli kayu-kayu yang bernilai, sangatlah mendesak keberadaannya dalam bidang perekonomian. Perkebunan kelapa sawit yang menggantikannya lebih memilih orang pendatang sebagai pekerja daripada orang Dayak. Hal yang demikian menyebabkan masyarakat adat merasa terpinggirkan atau tertinggalkan dalam kegiatan perekonomian penting di daerahnya mereka sendiri. Perilaku orang Madura terhadap orang Dayak dan keserakahan mereka yang telah menguras dan merusak alamnya menjadi salah satu dasar pemicu timbulnya konflik di antara mereka.

Ketidakcocokan di antara karakter mereka menjadikan hubungan kedua etnis ini mudah menjadi suatu konflik. Ditambah lagi dengan tidak adanya pemahaman dari kedua etnis terhadap latar belakang sosial budaya masing-masing etnis. Kecurigaan dan kebencian membuat hubungan keduanya menjadi tegang dan tidak harmonis.

\footnotetext{
${ }^{2}$ Simon Fisher, Dekka Ibrahim Abdi dkk. "Working With Conflict; Skills\& Strategies for Action, New York, 2002.Responding To Conflict.
} 
Ketidakadilan juga dirasakan oleh masyarakat Dayak terhadap aparat keamanan yang tidak berlaku adil terhadap orang Madura yang melakukan pelanggaran hukum. Permintaan mereka untuk menghukum orang Madura yang melakukan pelanggaran hukum tidak diperhatikan oleh aparat penegak hukum. Hal ini pada akhirnya orang Dayak melakukan kekerasan langsung terhadap orang Madura, yaitu dengan penghancuran dan pembakaran pemukiman orang Madura.

Konflik adalah hubungan antara dua pihak atau lebih (individu atau kelompok) yang memiliki atau merasa memiliki, sasaran-sasaran yang tidak sejalan. Kekerasan adalah tindakan, perkataan, sikap, berbagai struktur atau sistem yang menyebabkan kerusakan secara fisik, mental sosial atau lingkungan dan atau menghalangi seseorang untuk meraih potensinya secara penuh ${ }^{3}$

Dari definisi di atas, dapat dikatakan bahwa antara konflik dengan kekerasan bagaikan dua sisi mata pedang yang terpisahkan satu dengan yang lainnya manakala konflik yang terjadi tidak segera diselesaikan sebagaimana mestinya, sehingga menimbulkan kekerasan yang dapat merusak secara material maupun immaterial.

Konflik adalah suatu kenyataan yang tidak terhindarkan jika pihak-pihak yang bertentangan tidak memiliki pemahaman yang terhadap satu sama lain dan tujuan serta kebutuhan mereka tidak dapat lagi sejalan. Perbedaan pendapat yang terjadi di antara keduanya pada dasarnya adalah hal yang alami, namun jika tidak terkendali akan menjadi pemicu timbulnya kekerasan yang merusak kedua belah pihak bahkan lingkungan sekitarnya. Untuk itu diperlukan penyelesaian yang memberikan semangat damai pada kedua belah pihak. Jika konflik yang menyebabkan timbulnya kekerasan dapat diselesaikan tanpa melakukan kekerasan memberikan suatu rasa damai dan aman pada masyarakat sekitarnya. Sebaliknya, jika diselesaikan juga dengan kekerasan yang membabibuta akan menyebabkan timbulnya rasa takut, tidak aman, kepanikan bagi orang sekitarnya, khususnya bagian dari masyarakat yang bertikai. Permasalahan baru juga akan timbul dari penyelesaian dengan jalan kekerasan. .

Selanjutnya Simon Fisher dkk, mengajukan suatu konsep tentang arti kekerasan sebagai suatu pendekatan dalam intervensi konflik yang menyebutkan bahwa konflik adalah fakta kehidupan yang dapat memunculkan permasalahan-permasalahan berat saat kekerasan muncul dalam konflik tersebut. Oleh karenanya dapat dibedakan antara kelompok yang menghendaki kekerasan sebagai penyelesaian konflik dan kelompok yang anti kekerasan. Kelompok yang pro kekerasan cenderung untuk memaksakan kehendaknya agar dituruti orang lain ketika cara lain yang ditempuh gagal. Sedangkan kelompok anti kekerasan cenderung percaya bahwa kekerasan tidak akan mampu mendatangkan manfaat yang diharapkan diharapkan, sehingga penggunaan kekerasan dirasa tidak bermanfaat dan tidak adil. Secara praktis tindakan-tindakan anti kekerasan dilakukan masyarakat yang menerapkan metode anti kekerasan secara mutlak mereka lebih percaya bahwa metode anti kekerasan yang diterapkan dalam suatu konflik akan lebih berhasil dalam situasi yang mereka hadapi sendiri.

3 Simon Fisher, Dekka Ibrahim Abdi dan kawan. "Working With Conflict; Skills \& Strategies for Action, New York, 2002. Responding To Conflict. 
Menganalisa lebih lanjut tentang konflik horizontal yang terjadi pada beberapa wilayah di Indonesia, seperti konflik Dayak dan Madura dihubungkan dengan teori Simon Fisher, dapat dikatakan bahwa sebagian besar masyarakat di daerah konflik cenderung memilih jalan kekerasan sebagai alternative penyelesaian masalah yang muncul di antara mereka. Mereka menganggap cara ini lebih membuat pihak lawan memenuhi keinginan mereka.

Identitas yang terancam sebagai suatu suku asli Kalimantan yang terusik oleh kedatangan pendatang membuat suku Dayak mengambil sikap keras. Ditambah lagi dengan tidak adanya perubahan sikap dari masyarakat pendatang. Hal ini jelas terlihat pada dampak yang terjadi pasca konflik horizontal Dayak dan Madura. Mereka tidak melihat dampak dari kekerasan bagi masyarakat mereka sendiri yaitu korban jiwa dan harta benda, tetapi yang terpenting adalah keluarnya orang Madura dari wilayah mereka.

Menyimak lebih jauh tentang konflik horizontal yang juga disebut sebagai konflik etnis yang bersifat laten (tersembunyi) yang harus diangkat ke permukaan agar dapat ditangani secara efektif. Disebut sebagai konflik yang bersifat laten karena di antara kedua etnis yang bertikai (Dayak dengan Madura) sudah lama terjadi ketidakharmonisan dalam interaksi sosialnya. Suku Dayak sebagai suku asli Kalimantan merasa terusik kehidupannya dengan semakin meningkatnya populasi suku Madura yang juga mendominasi hampir seluruh aspek kehidupannya.

Ketidakharmonisan dalam interaksi sosial antara kedua etnis ini tidak cepat mendapat penanganan dari tokoh masyarakat setempat maupun oleh aparatur pemerintah agar dapat ditangani. Pada pertikaian yang terjadi terlihat adanya keberpihakan dari aparat kepada salah satu etnis menurut pendapat etnis lain. Kondisi ini terus berlanjut, yang pada akhirnya menjadi konflik terbuka berakar dan diiringi dengan kekerasan.

Konflik yang dipicu oleh persoalan yang sederhana, menjadi kerusuhan dan di identifikasi pemicu pecahnya konflik adalah : adanya benturan budaya etnis lokal dengan etnis pendatang, lemahnya supremasi hukum, adanya tindak kekerasan. Benturan budaya ini sebenarnya lebih banyak disebabkan oleh kesombongan dan ketidakpedulian etnis Madura terhadap hukum adat dan budaya lokal yang sangat dihormati masyarakat setempat seperti hak atas kepemilikan tanah.

\section{PENANGANAN YANG DILAKUKAN}

Lemahnya supremasi hukum terlihat dari perlakuan yang ringan diberikan pada masyarakat Madura. Dalam hal ini untuk menghindari keadaan yang lebih tidak terkendali lagi seperti terjadinya tindakan kekerasan, pembunuhan, pembakaran dan pengusiran yang berkepanjangan, maka untuk sementara waktu orang Dayak menyatakan sikap yaitu :

1. Untuk etnis Madura yang masih berada di wilayah Kalimantan Barat agar secepatnya dikeluarkan atau diungsikan demi keselamatan dan keamanan mereka karena tidak ada 
jaminan untuk itu. Terlebih dengan tidak cukupnya aparat keamanan menjangkau wilayah rawan konflik.

2. Menolak pengembalian pengungsi etnis Madura untuk batas waktu yang tidak ditentukan karena tidak adanya suatu jaminan perubahan sikap dari etnis Madura dan juga dikhawatirkan adanya tindakan balas dendam secara langsung maupun tidak langsung.

Sikap ini ditanggapi positif oleh aparat penegak hukum maupun masyarakat karena adanya keterbatasan aparat yang tidak dapat menjangkau seluruh wilayah Propinsi Kalimantan, maka demi keamanan kedua belah pihak untuk sementara suku Madura harus dilokalisir pada daerah yang lebih aman. Selain itu dalam upaya penanganan konflik yang terjadi ini dilakukan juga beberapa cara yaitu :

(1) Untuk sementara waktu yang tidak dapat ditentukan batasnya, etnis Dayak dan Melayu sepakat tidak menerima kembali etnis Madura di bumi Kalimantan terutama di daerah konflik . Hal ini dilakukan agar tidak terjadi bentrokan di antara mereka karena sangat rentan tersulut oleh isu yang akan membakar kemarahan kedua belah pihak;

(2) Rehabilitasi bangunan yang rusak akibat pengrusakan dan pembakaran terhadap infrastruktur masyarakat umum juga dilakukan agar dapat berjalannya kegiatan masyarakat sebagaimana mestinya. Moral dan mental masyarakat juga perlu mendapat perhatian dan pembinaan agar terwujud suatu rekonsiliasi yang damai dan melibatkan kembali seluruh tokoh masyarakat;

(3) Re-evakuasi dilakukan bagi korban konflik ke daerah yang lebih aman. Untuk itu perhatian terhadap keamanan mereka di daerah pengungsian harus didukung oleh pihak keamanan sampai mereka mendapat tempat yang layak;

(4) Dialog antar etnis yang berkesinambungan dengan memanfaatkan lembaga adat masyarakat perlu dilakukan dalam proses pembentukan kerjasama mengakhiri konflik yang berkepanjangan;

(5) Demikian juga dengan penegakkan hukum terhadap pelaku pelanggaran hukum perlu dilakukan secara konsisten dan adil tanpa berpihak pada etnis tertentu selain itu kemampuan personil petugas keamanan perlu ditingkatkan.

\section{KESIMPULAN}

Dari penelitian ini dapat disimpulkan bahwa penyebab terjadi konflik adalah kurangnya pemahaman terhadap sosial budaya masing-masing suku yang berbeda antara suku Dayak dan Madura. Selain itu kurang diperhatikannya peranan masyarakat setempat dalam kegiatan perekonomian di wilayah mereka, sehingga timbul diskriminasi terhadap suku Dayak sebagai suku Asli setempat. Selain itu dalam sejarah konflik di Kalimantan secara umum dipicu oleh dipraktekkannya tindak kekerasan baik dalam bentuk penganiayaan dan pembunuhan manusia di daerah konflik. Hal ini didukung juga dengan lemahnya supremasi hukum dan perlindungan terhadap hak asasi manusia. 


\section{SARAN}

Dari penyebab timbulnya konflik maka disarankan agar :

- Perlunya diadakan pendekatan terhadap tokoh masyarakat setempat tentang pemahaman akan budaya dan adat istiadat suku yang ada, sehingga terjalin hubungan yang lebih baik antara suku Dayak dengan Madura

- Aparat penegak hukum hendaknya bertindak tegas dan konsisten terhadap pelanggaran hukum yang terjadi sehingga tidak menimbulkan diskriminasi.

- Perlu dilakukannya introspeksi dari kedua belah pihak agar tidak terjadi lagi pertikaian dengan kekerasan yang berakibat pada banyaknya korban jiwa.

- Perlunya pemerintah mengembangkan kemampuan orang Dayak dalam berusaha dan mengolah sumber daya alamnya agar tidak terjadi kesenjangan yang menimbulkan konflik, disamping itu juga peraturan yang memberikan kesempatan bagi masyarakat lokal untuk membangun wilayahnya agar tidak membuat mereka terisolasi dan mengalami ketertinggalan.

\section{DAFTAR PUSTAKA}

Alqadarie Syarief I. (20008). Laporan Akhir Hasil Penelitian Pertikaian antar Komunitas Madura Kalimantan Barat dengan Dayak 2007/2008 dan antara Komunitas Madura Sambas dengan Melayu Sambas Tahun 2007/2008 di Kalimantan Barat. Kerjasama Yayasan Ilmu-ilmu Sosial Jakarta-dengan Fisipol Untan-Pontianak.

Fisher Simon, Ibrahim Dekka, dkk. (2002) “Working with conflict' : Skill \& Strategies for Action. New York.Responding To Conflict.

Jurnal Hukum dan Pemikiran Nomor I, Tahun 2 Januari- Juni 2008.

Laporan Khusus Gubernur Kalimantan Barat 2007.

Soekanto Soeryono; 1990. Suatu Pengantar. Raja Wali Press, Jakarta.

Sunaryo Thomas. "Manajemen Konflik dan Kekerasan”. Makalah pada Sarasehan tentang Antisipasi Kerawanan Sosial di DKI Tanggal 15-17 September 2002. 